\title{
Animals and Political Community: Preliminary Reflections Prompted by Bill C-10'
}

\author{
F.C. DECOSTE
}

The author examines the proper place of animals in the political morality of law and politics. He reconstructs the political morality of the law of animals in liberal states, and characterizes the effect. if any, of Bill C-10 on that morality. He suggests that animal welfarist and rights views are mistaken when assessed against the requirements of liberal personal and political morality. He concludes that the changes contemplated in Bill C-10 are destructive in their approach to liberal political morality, and of the proper stature of animals in our moral imaginations.
L'auteur examine la place correcte que les animaux devraient occuper dans la moralité politique du droit et de la politique. Il reconstruit la moralité politique du droit des animaux dans les États libéraux et caractérise les effets. s'il y a lieu. du projet de loi C-10 sur celte moralité. Il suggère que les adeptes du bien-etre et des droits des animaux se trompent lorsque leurs opinions sont comparees à la moralité libérale personnelle et politique. II prévient que les changements préconisés dans le projet de loi C-10 sont destructifs dans leur démarche à l'égard de la moralité politique libérale et à la place que les animaux devraient occuper dans notre imagination morale.

TABLE OF CONTENTS

I. INTRODUCTION .................... 1057

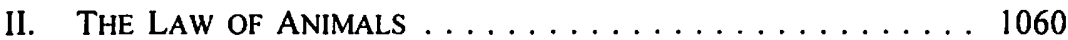

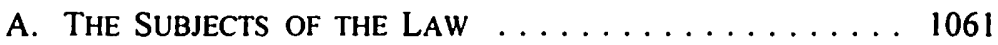

B. ANIMALS AND THE LAW'S MORALITY ........ 1063

III. BILl C-10: EXTENDING THE BIOLOGIC CONTINUUM $\ldots \ldots 1066$

IV. Conclusion: Calculating Consequence . . . . . . 1070

Morality requires nothing at all of animals.

- Judith Jarvis Thomson ${ }^{2}$

\section{INTRODUCTION}

Thomson, of course, is right. Animals are not thought by us to owe duties to us or, for that matter, to one another, ${ }^{3}$ because we think them not to be subjects of morality

Professor, Faculty of Law, University of Alberta.

Bill C-10, An Act to Amend the Criminal Code (Cruelty to Animals and Firearms) and the Firearms Act, 37th Parl., 2d Sess. 2003 (introduced and deemed to have passed all stages in the House of Commons on 9 October 2002). For full legislative summary see Gérald Lafreniere, Legislative Summary LS-433E, online: <www.parl.gc.ca/common/Bills/_ls.asp?lang=E\&Parl= $37 \& S e s=2 \& 1 s=C 10 \&$ source=Bills_House_Government $>$ (date accessed: 10 March 2003). The Bill is now before the Senate. See J. Aubry, "Animals cruelty bill in jeopardy" Edmonton Journal (15 December 2002) A5; B. Curry, "Bill threatens stampedes, senators warn" National Post (28 October 2002) A5; \& D. Johnston, "Still waiting for teeth in our animal-abuse law" Globe \& Mail (7 October 2002) Al.

$2 \quad$ J. Jarvis Thomson, The Realm of Rights (Cambridge: Harvard University Press, 1990) at 217.

3 That in ancient Greece and during the medieval period animals were sometimes put on trial is not evidence that our views of animals as extra-moral beings is itself contingent, since those trials had more to do with the moral requirements of humans than with the moral capacities of animals. See 
at all. ${ }^{4}$ Yet we have long thought that, though animals are not the subjects of duty in either of these senses, they are nonetheless the objects of duties that fall on morality's proper subjects, ourselves. We are allowed to think this because our understanding that animals owe us nothing itself implies nothing as regards either their status in a properly conceived morality or the duties which such a conception may impose upon us with respect to them. ${ }^{5}$

Arguments concerning the proper place of animals in our moral imaginations, whatever the differences between them, sound in either of two impulses. ${ }^{6}$ According to what may be termed the "welfare" proposal, we have obligations towards animals because how we treat them is, somehow or another, important to us. Under this view, animals are the indirect beneficiaries of our duty to maintain whatever it is about ourselves to which their proper treatment is thought essential. According to the "rights" proposal, the duties we owe animals are not about us at all, but about them, because they are beings who are rights-holders. Under this much more robust view, animals cease to be the objects of our moral interests and become instead, in some sense and to some extent, persons in morality's domain: beings who, like us, have their own freestanding interests. Though fundamentally different in these ways, the welfare and rights views share a common point of departure (that animals count at all morally, because they are sentient and may, in consequence, suffer at our hands ${ }^{7}$ ) and, in the final

P. Schiff Berman, "Rats, Pigs, and Statues on Trial: The Creation of Cultural Narratives in the Prosecution of Animals and Inanimate Objects" (1994) 69 N.Y.U. L. Rev. 288.

$+\quad$ Our thinking this does not require us to subscribe to any notion of human exceptionalism: it requires only a recognition of the profound, incommensurable, irredeemable (and, I will later argue, mysterious) difference between animals and us. Human exceptionalism proceeds from the understanding that difference means, simply and exclusively, that animals are not our equals; and it informs two prescriptions concerning our relationship to them, namely, that we are either their stewards and custodians or else their masters. For discussion of the stewardship and domination positions, see L. White, "The Historical Roots of Our Ecological Crisis" (1967) 21I Science 1203; L. Steffen, "In Defense of Domination" (1992) 13 Environmental Ethics 63; T. Regan, The Case for Animal Rights (Berkeley: University of California Press, 1983); P. Singer \& T. Regan, eds., Animal Rights and Human Obligations (Englewood Cliffs: Prentice-Hall, 1989); and P. Singer, ed., In Defence of Animals (Oxford: Blackwell, 1985).

For an argument along these lines in the context of animal rights, see M.H. Kramer, "Do Animals and Dead People Have Legal Rights?" (2001) 14 Can. J. L. \& Jur. 29 at 41-43. Rawls also separates duty-owing from the capacity to owe duties, though he then segregates animals. See $J$. Rawls, $A$ Theory of Justice (Cambridge: Harvard University Press, 1971) at 512: "While I have not maintained that the capacity for a sense of justice is necessary in order to be owed the duties of justice, it does seem that we are not required to give strict justice anyway to creatures lacking this capacity." He goes on to claim that "it does not follow that there are no requirements at all in regard to them" and to proscribe - as a moral matter and not as a matter of justice - cruelty towards them (ibid.). For commentary on Rawls, see R. Garner, "Political Ideology and the Legal Status of Animals" (2002) 8 Animal L. 77 at 86-89.

" On this distinction see, e.g., G.L. Francione, Animals, Property, and The Law (Philadelphia: Temple University Press, 1995) at 6-7, 253-54; and L. Gruen, "Animals" in P. Singer, ed., $A$ Companion to Ethics (Oxford: Blackwell, 1991) 343.

For an insightful analysis of the moral duty to relieve suffering, see J. Mayerfeld, Suffering and Moral Responsibility (New York: Oxford University Press, 1999). 
analysis, a prescription as well (that, because animal suffering counts, making them suffer constitutes cruelty). ${ }^{8}$

However, that we are on either account obliged not to cause suffering to animals does not mean that it is proper for the law to enforce that obligation by constraining our liberty. The immorality of a practice is never sufficient reason for making it illegal, even when the morality in question is, consciously and in content, a liberal morality. This must be so, not only because, were the law always to enforce the right, liberty might vanish, but also because, conceptually, the law is an expression of liberal political morality and not liberal morality tout court. Liberal political morality and liberal personal morality have decidedly different objects - the one the right ordering and constraint of public institutions, and the other the moral consequences and demands for life-living of taking others seriously as individuals - and they are also distinct in terms of their place in a properly conceived liberal community. ${ }^{9}$

Unfortunately, animal welfarists and animal rightists alike offer very little of consequence as regards the legal repercussions of their views or in support of the leap they recommend from the moral to political. Rather, both seem content to rely on vaguely articulated notions of moral progress that, in my view, are more productive of exhortation than analysis. ${ }^{10}$ Following Bentham in this respect," proponents of the reception into law of our duties to animals generally associate the progress of equality with the widening of law and politics, and draw on analogies between the present situation of animals and the former situation of slaves and women. ${ }^{12}$ Now, quite apart

Care must be taken not to overstate this unity. The welfare and rights views remain fundamentally different because their ultimate concerns differ so markedly. Animal welfarism terminates in the issue of animal suffering; in the animal rights view, in contrast, the ultimate concern is personhood and, in consequence, the issue becomes finally killing or, more accurately, when, if ever, humans may properly take the lives of animals.

So far as the conduct of our public and private lives is concerned, everything, at least in liberal terms, turns on the place of the legal, the political, and the private in our political imagination and practices. In my view, a properly liberal view of this geography will place the legal (and, therefore, the constraint of politics) at the heart of matters public, will allow the political public purposes subject to legal constraint, and will segregate personal morality, including liberal personal morality. to a private and therefore legally and politically disabled sphere.

See generally J.M. Jasper \& D. Nelkin, The Animal Rights Crusade: The Growth of a Moral Protest (New York: Free Press, 1992).

1 Bentham put the matter thus:

The day may come when the rest of the animal creation may acquire those rights which never could have been withholden from them but by the hand of tyranny. The French have already discovered that the blackness of the skin is no reason why a human being should be abandoned without redress to the caprice of a tormentor. It may one day come to be recognized that the number of legs, the villosity of the skin, or the termination of the os sacrum are reasons equally insufficient for abandoning a sensitive being to the same fate.

See J. Bentham, An Introduction to the Principles of Morals and Legislation, J.H. Burns \& H.L.A. Hart, eds. (London: Athlone Press, 1970) at 283, footnote.

12 For analogies in both regards, see S.M. Wise, Ratling the Cage: Towards Legal Rights for Animals (Cambridge: Perseus Press, 2000). As regards women, see Peter Singer, who begins his widely influential Animal Liberation (New York: New York Review Books, 1975) with a commentary (at 1) on Mary Wollstonecraft's Vindication of the Rights of Women. Sometimes, animal rights activists push analogies of this sort to destinations that the settled convictions of most find morally repugnant. For example, recently, People for the Ethical Treatment of Animals 
from any historical ${ }^{13}$ or conceptual ${ }^{14}$ relationship that may, or may not, obtain between our treatment of animals and the progress of replacing hierarchical structures with equality, none of this answers the question that matters most as regards the governance through law of the relationship between animals and ourselves - namely, the question of the proper place of animals in the political morality of liberal law and politics.

It is my intention in this article to sketch an answer to this question and, by so doing, to make room for certain suggestions concerning the significance, beyond and through the law, of animals to the moral life and experience of persons in liberal societies. I shall first attempt to reconstruct the political morality that the law of animals of liberal states, as traditionally conceived, expresses. Next I shall briefly characterize what I take to be the changes to that morality occasioned by the terms of Bill C-10. By way of a brief conclusion, I shall argue that those changes carry consequences that are at once both inimical to liberal political morality and destructive of the stature and significance which animals, as our true and forever alien Other, ought properly to have in our moral imaginations. Though I can here offer only a preliminary case, $I$ intend to suggest throughout that the welfarist and the rights views are each mistaken when assessed against the requirements of liberal personal and political morality.

\section{The Law of Animals ${ }^{15}$}

Though the political morality it expresses finds varied and contested expression in liberal political philosophy (and though liberal political philosophy in turn is connected to, and somehow descends from, liberal morality as such), law is not philosophy. Nor, more specifically, does it depend upon some systematic epistemology or ontology. This is not, of course, to concede that there is no legal knowledge or that law has no sense

(PETA) ran advertisements nationally that drew an analogy between the murder of women in British Columbia - the so-called Pickton case - and the killing of animals industrially. See 1 . Bailey, "Animal Rights Ad Plays Off Pickton Case" National Post (14 November 2002) Al, All; and H. Morris, Letter to the Editor, National Post (15 November 2002) A19. Not content with that controversy, more recently still, PETA erected a website that compares the killing of animals to the Holocaust. See online: <www.masskilling.com> and M. Friscolanti, "Jews Outraged by Ad Linking Animal Slaughter to Holocaust" National Post (26 February 2003) A8. The brief concluding section of this essay will perhaps indicate why, given certain changes to our understanding of animals, such destinations are unavoidable.

For an argument that seeks - in my view, with much success - "to de-couple animal protection from the history of social liberation," see K. Kete, "Animals and Ideology: The Politics of Animal Protection in Europe" in N. Rothfels, ed., Representing Animals (Bloomington: Indiana University Press, 2002) 19. See also B. Sax, Animals in the Third Reich: Pets, Scapegoats, and the Holocaust (New York: Continuum, 2000).

it See infra note 31 and accompanying text.

is See E.L. Hughes \& C. Meyer, "Animal Welfare Law in Canada and Europe" (2000) 6 Animal L. 23; D. Favre \& V. Tsang, "The Development of Anti-Cruelty Law During the 1800 's" (1993) Det. C.L. Rev. 1; S.A. Sochnel, "What Constitutes Offense of Cruelty to Animals - Modern Cases" (1992) 6 A.L.R. 5th 773; A. Dichter, "Legal Definitions of Cruelty and Animal Rights" (19781979) 7 B.C. Envtl Aff. L. Rev. 147; C.E. Friend, "Animal Cruelty Laws: The Case for Reform" (1974) 8 U. Richmond L. Rev. 201; and D.E. Buckner, "What Constitutes Statutory Offense of Cruelty to Animals?" (1962) 82 A.L.R. 2d 794. 
of the beings that are the subjects of its dominion. It is, however, to claim that law proceeds, not from theoretical abstractions, but from its own immanent suppositions about knowledge and about legal subjectivity, suppositions that lawyers find in the traditions of practice of which the law is comprised. Because these epistemic and ontic suppositions are unearthed as standing agreements that tradition allows, they are posited more as points of argumentative departure than as abstract positions produced by legal, let alone philosophical, reflection and interrogation. Sunstein ${ }^{16}$ has aptly described this characteristic of our law as incomplete theorization, which he claims resides in the "presumption against high-level theories," and which he regards as "an aspect of the rule of law."

Now, this understanding is important in the present context just because most participants in the ongoing debate about the place of animals in our law seem to me to think that the matter stands rightly to be resolved by abstraction bred of philosophizing. Clearly, if, as I believe, incomplete theorization is a necessary incident of liberal law, then looking for answers in abstractions concerning which agreement seems improbable and improper is a mistaken investment. Nor only that: undertakings of this bent misdirect inquiry away from the necessary task of constructing the agreement concerning legal subjectivity on which the place of animals in our law properly depends. Here I propose first to state that agreement, and then to associate it with what I take to be a cardinal feature of liberal political morality.

\section{A. The SUBJECTS OF THE LaW}

Let us state the background agreement straightaway: Animals are subject to the law, but they are not subjects of the law. This agreement is a necessary consequence of the law's understanding of subjectivity, and it places animals in a special and distinct position in our law. I shall briefly attend to both matters, before turning to the question of the political morality which the agreement expresses and on which its justification depends.

Law's domain is defined by the birth and death of its human subjects. Neither the fetus nor the corpse is a subject of the law, though, like animals, both may properly be subject to the law. It is often proposed - including, notably, by those who would change the status of (some) animals at law ${ }^{18}$ - that this is so because legal c. 2. See also C.R. Sunstein, "Incompletely Theorized Agreements" (1995) 108 Harv. L. Rev. 1733.

18 The logic of this subscription is as follows: if the meter of legal subjectivity is agency, and if the law recognizes the subjectivity of the mentally incompetent despite their patent lack of agency, and if, finally, at least some animals can be shown to possess more actual agency than the incompetent, then the law is bound, by reason of a logic bred of its own conviction, to recognize at least some animals as subjects. This, of course, is an argument from the marginal case, and it has a long pedigree in philosophical discourse about the status of animals. Bentham, for instance, offered just such an argument: "What else is it that should trace the insuperable line? Is it the faculty of reason, or, perhaps, the faculty of discourse? But a full-grown horse or dog, is beyond comparison a more rational, as well as a conversible animal, than an enfant of a day, or a week, or even a 
subjectivity is synonymous with moral agency. But this is wrong. Our law captures as its subjects not only those who are or will become "mentally competent human adults," 19 but those as well whose irredeemable mental incompetence disqualifies them as moral agents. Legal subjectivity, rather, is bounded by birth and death because the meter of subjectivity is constitutional presence. It is being present for and with others, whatever the particulars of competence and capability, that makes each of us a legal being, that renders the fetus before, and the corpse beyond, rights, and that makes possible the constitutional fellowship which we term political community. ${ }^{20}$ Now, make no mistake, this makes legal subjectivity and legal equality a function and expression of the biological unity of humankind. ${ }^{21}$ However, as I shall argue later in this piece, everything - for us and for animals - turns on this being so.

What then of animals? The law denies them fellowship, yet it makes them subject to its rule. The law's story about animals does not, however, end with this. The narrative continues, wonderfully in my view, in the details of the place that the law builds for them. Every first-year law student knows - incorrectly it turns out - that persons are subjects of law and all else in human experience consists of things that are subject to law as property. But the law of animals belies this too-glib dichotomy. Beyond subjectivity, there are indeed many, and mostly, things. But there as well, in a special category superior to things and intermediate between things and persons are the corpse and the fetus and the animal. ${ }^{22}$ As regards two of these beings, our law

month, old" (supra note 11 at 283). Most contemporary proponents of animal rights have blown Betham's comment en passant into a full-fledged scholarly and political agenda. See, e.g., S.M. Wise, Drawing the Line: Science and the Case for Animal Rights (Cambridge: Perseus, 2002). In my view, even were agency the meter of legal subjectivity, arguments from the marginal case would only possibly assist the case for animal rights, if it could be shown that the law's treatment of the mentally incompetent either expressed no other foundational value or a value that, on some reasonable ground, is unacceptable. Kramer, supra note 5 at 33 .

Lyotard puts these matters thus:

A human being has rights only if he is other than a human being. And if he is to be other than $a$ human being, he must in addition become an other human being. Then "the others" can treat him as their fellow human being. What makes human beings alike is the fact that every human being carries within him the figure of the other. The likeness that they have in common follows from the difference of each from each.

J.-F. Lyotard, "The Other's Rights" in S. Lukes \& S. Hurley, eds., On Human Rights: The Oxford Amnesty Lectures 1993 (New York: Basic Books, 1993) 135 at 136.

21 As again put in Lyotard, ibid.: "What is this figure of the other in me, on which, it is said, my right to be treated as a human being rests?... Each human being is a specimen of this species. He resembles any other member of the species, as a chimpanzee resembles a chimpanzee."

22

The experience of the moral difference between things and persons and animate non-human life is sometimes said - in my view correctly - to constitute a revolutionary moment in human consciousness:

If one imagines oneself back at an early moment in culture during which a large knife is suspended above a child (Isaac, Iphigenia, any child), and if before the knife falls, the child is moved out of that space and an animal, goat or lamb, is put in its place, that moment of substitution will be recognizable as one that has always (in the retrospective accounts of the culture that followed) been designated a revolutionary moment in the growth of moral consciousness. But if one now holds steadily visible not two pictures but three pictures the child and the knife looming above, giving way to the lamb and the knife looming above, and now in turn the lamb is moved out of that location and replaced by a block of wood 
presently prescribes treatment akin to the respect owed to persons, treatment that proscribes acts of cruelty and disrespect. That animals may become property does not compromise the integrity of this category any more than does the property-hood of the corpse make jest of the special obligations of respect owed by us to it. Indeed, instead of contradiction, we find complementarity. ${ }^{23}$ But if animals, along with the fetus and the corpse, are beings of some sort and not merely things subject to the law, then it must somehow be by reason of the requirements of the political morality that our law, on the pain otherwise of irrationality, must in all of its parts express.

\section{B. ANIMALS AND THE LAW'S MORALITY}

It is very often proposed that the way the law treats animals is a consequence of the moral sensibilities required of humans to live successfully in political community. One Court, in constructing the political morality of anti-cruelty law, put this view of the matter as follows:

Cruelty to them manifests a vicious and degraded nature, and it tends inevitably to cruelty to men.... The dominion of man over them, if not a moral trust, has a better significance than the development of malignant passions and cruel instincts. Often their beauty, gentleness, and fidelity suggest the reflection that it may have been one of the purposes of their creation and subordination to enlarge the sympathies and expand the better feelings of our race. But. however this may be, human beings should be kind and just to dumb brutes; if for no other reason than to learn how to be kind and just to each another. $^{24}$

This, of course, is a welfarist - and morally, a very Kantian ${ }^{25}$ - conception of the

under the still looming knife - so great in the transition from the second to the third picture is the revolution in consciousness that the object itself is now re-perceived as a wholly different object, a tool rather than a weapon, and the anticipated action of the object is no longer an act of "wounding" but an act of "creating."

E. Scarry, The Body in Pain: The Making and Unmaking of the World (New York: Oxford University Press, 1985) at 174.

See for instance Backhouse v. Judd, [1925] South Australian State Reports 16 at 21:

There is nothing novel in the idea that property is a responsibility as well as a privilege. The law which confers and protects the right of property in any animal may well throw the burden of the responsibility for its care upon the owner as a public duty incidental to the ownership.

That the practice of our law has not protected, properly and fully, many animals, particularly those owned and raised by industrial farming, is an indictment, in my view, of the fidelity of the law's practitioners, rather than of the law's conception of the place of animals and of the protection and respect owed to them. See Garner, supra note 5 at 91 (arguing that "the case for moderating or abolishing the property status of animals has been exaggerated" and that "it is neither a sufficient nor necessary step towards a relatively high level of protection for animals"). I owe my colleague, Dr. Rob Chambers, for drawing my attention to the Backhouse case. Stephens v. State, 3 So. 458 at $458-59$ (1888).

is Kant's welfarism is pure and foundational to all subsequent versions:

So far as animals are concerned, we have no direct duties. Animals are not self-conscious and are there merely as a means to an end. That end is man.... Our duties to animals are merely indirect duties towards humanity. Animal nature has analogies to human nature, and by doing our duties to animals in respect to manifestations which correspond to manifestations of human nature, we indirectly do duty to humanity.... If then any acts of 
law of animals: the law properly requires that we treat them well because treating them well helps us to cultivate in ourselves the moral sensibilities that we require to live lives governed by law. Animals are, accordingly, instruments of our moral improvement, and the law which governs our treatment of them has exclusively to do with their political value for us.

It seems to me that this will not do as an account of the political morality of the law of animals. I am not here relying on any of the well-known arguments to which Kantian positions of this sort are so very vulnerable. ${ }^{26} \mathrm{My}$ dissent concerns other, more political matters, and begins with the welfarist view that we cannot owe duties, at law, to beings who are fundamentally different from us for their own sakes. Now, as between the human subjects of law, fundamental difference does not obviate duty: just the contrary, our law imposes greater duties on us as regards those who, like the mentally disabled or the persistently vegetative, are profoundly different from and vulnerable to us. And our law imposes upon us duties of respect and dignified treatment regarding human remains, "beings" of course that are not subjects of law at all and that are fundamentally and incomprehensibly different from us. It is, I believe, in the political morality of obligations such as these, towards the flagrantly vulnerable Other, that our duties to animals sound - for their own sakes and not ours.

For reasons of space, I cannot offer a detailed analysis of the political morality that founds our non-instrumental duties to the mentally incompetent, the corpse, and, 1 believe, the fetus. In the place of that account, I will proceed by simple statement of

animals are analogous to human acts..., we have duties towards the animals because thus we cultivate the corresponding duties towards human beings.... If he is not to stifle his human feelings, he must practise kindness towards animals, for he who is cruel becomes hard also in his dealings with men.... Tender feelings towards dumb animals develop humane feelings towards mankind.... [A]nimals must be regarded as man's instruments.

I. Kant, Lectures on Ethics, trans. L. Infield (New York: Harper Torchbooks, 1963) at 239-40. For commentary see J. Skidmore, "Duties to Animals: The Failure of Kant's Moral Theory" (2001) 35 Journal of Value Inquiry 541; and L. Denis, "Kant's Conception of Duties Regarding Animals: Reconstruction and Reconsideration" (2000) 17 History of Philosophy Q. 405.

If you felt like snapping your fingers, perhaps to the beat of some music, and you knew that by some strange causal connection your snapping your fingers would cause 10,000 contented, unowned cows to die after great pain and suffering, or even painlessly and instantaneously, would it be perfectly all right to snap your fingers? Is there some reason why it would be morally wrong to do so?

Some say people should not do so because such acts brutalize them and make them more likely to take the lives of persons, solely for pleasure. These acts that are morally unobjectionable in themselves, they say, have an undesirable moral spillover. (Things then would be different if there were no possibility of such spillover - for example, for the person who knows himself to be the last person on earth.) But why should there be such a spillover? If it is, in itself, perfectly all right to do anything at all to animals for any reason whatsoever, then provided a person realizes the clear line between animals and persons and keeps it in mind as he acts, why should killing animals tend to brutalize him and make him more likely to harm or kill persons? Do butchers commit more murders?

R. Nozick, Anarchy, State, and Utopia (New York: Basic Books, 1974) at 36. See also Skidmore, supra note 25 at $556-57$. 
the conclusion that such an account would compel, and then explore its significance to the duties we owe at law to animals.

A liberal political community is a community of conviction concerning the place of others in our lives, and it becomes a community of character because of the place its moral convictions construct for others. Dworkin puts this matter well: liberal political community, is a community bred of principles that "command ... that no one be left out, that we are all in politics together for better or for worse, that no one may be sacrificed, like wounded on the battlefield."27 A community of this character is a community for which difference and powerlessness and vulnerability are the motivation and meter of law and politics. Indeed, the rule of law founds our law, and anchors and constrains our politics, just because our political community is committed above all else to ensuring that powerlessness and vulnerability define the lives of none of us. Now such a community, I want to suggest, will be a community open to otherness and solicitous of otherness, including alien otherness, not because it improves community, but because it is a community of that character. It is for that reason I believe that conduct towards the corpse (and where it is regulated, the fetus) is considered by our law to be otherregarding conduct and not conduct that in its true and final character is self-regarding.

Animals are profoundly different from us, and they are profoundly vulnerable to us. None of us can imagine what it means to be a dog or a cat or a bat or an ape, or what that thing we call life is like for them. ${ }^{28}$ Our moral imagination necessarily stops at consciousness of their difference from us, because with and in them, we "encounter a fundamentally alien form of life." 29 Unlike the fetus or the corpse or the profoundly mentally disabled, concerning each of which empathy of some kind is possible, animals are for us the end of empathy. They are, in consequence, true Others, beings beyond the reach of solidarity and forever resident, for us, in mystery. These mysterious beings with whom we share time and space are defined as well, from our point of view, by their flagrant vulnerability to us. We are in a position of complete dominion over them, and because we are, animals - individually and collectively - stand or fall according to the quality of our attitudes and actions towards them. ${ }^{30}$

Now a political community such as ours, constituted by the conviction to save blameless and safe from power vulnerable difference, has reason of principle, when confronted with alien and vulnerable Otherness, to act toward that Otherness in ways moved by and consonant with the character of the kind of community it is. In my view, in the absence of receiving animals as persons and ascribing rights to them on that basis, this understanding alone can ground a place for animals in our political and legal theory and practice that takes them seriously as beings, not merely worthy but demanding of our concern, respect, and protection. I caveat the rights proposal because,

28 See T. Nagel, "What is it like to be a bat?" in T. Nagel, Mortal Questions (Cambridge: Cambridge University Press, 1979) 165.

29 Ibid. at 168 [emphasis in original].

30 For an intriguing, even if, in its Kantian details, mistaken exploration of our dominion over animals, see M. Scully, Dominion: The Power of Man, the Suffering of Animals, and the Call to Mercy (New York: St. Martin's, 2002). 
for reasons which will hopefully become apparent, I think it rife with possibilities disastrous both for them and for us. I exclude instrumental understandings as a way of taking animals seriously simply because, by making them a means for our political virtue, it removes from them any independent moral status or force in our lives and affairs. The character of community understanding I have here sketched avoids, I believe, both courting the aforementioned disastrous consequences and trivializing these wonderfully mysterious beings with whom we occupy this planet. And to repeat, it founds our law with respect to animals on the duty - but perhaps as much, on the proclivity - that we act in ways that accord with the character that we claim is constitutive of the people we are. Such a community will be moved, by reason of character, by the principle of taking upon itself the suffering otherwise possible by its conduct, of the pure and vulnerable Others that surround it. And though illiberal political communities could be, and have been ${ }^{31}$ moved to recognize and protect animals, the origins and motivations of their doing so will differ, necessarily and starkly, from the origins and motivations of the practice of recognition and protection in liberal community. Liberal community alone will be moved by the commitment to constrain the proclivity of power to punish difference; and only in liberal political community will that commitment raise the recognition and protection of animals to a duty resident at the heart of its politics.

\section{Bill C-10: Extending the Biologic ContinuUm}

Bill C-10 is bad law because it blurs the distinction between persons and animals. Its badness resides in certain consequences, for us and for animals, that follow from this, to which I shall briefly attend in the next section. Here I want to make the case that the compromise of this distinction, at once critical and foundational to our law, is indeed the Bill's effect and its intent.

So far as the law of crimes is concerned, ${ }^{32}$ the law of animals, as it stood before

$3 \quad$ See supra note 13.

"2 Of course, the law governing our treatment of animals is found for the most part in civil law passed by the provinces and territories and, to a lesser extent, in federal legislation that has nothing to do with criminal law. See Hughes \& Meyer, supra note 15 . Though I intend not to pursue the matter here - and not only because I remain uncertain of it - a case can be made that the law of crimes of a liberal state ought not to govern the treatment and protection of animals. This argument proceeds from what many take to be the threshold principle of the general part of the criminal law, namely, that the criminal law should only be used to censure people for substantial wrongdoing, that is, for other-regarding conduct that causes substantial harm to other persons. Of course, unless we were, contrary to our tradition, to accept animals as persons, this principle would forbid the state authority to govern the relationship between animals and its citizens through the criminal law power. The contemporary practice of states shows a pronounced disinclination to be bound by this principle or by our traditions concerning legal and political subjectivity. For example, only recently thirty-seven American states have made certain forms of animal cruelty a crime; and Germany has amended its constitution to provide animals constitutional status: see $M$. Pollan, "An Animal's Place" The New York Times Magazine (10 November 2002) 58. Though the Law Reform Commission of Canada has in the past declared our criminal law to be bound by this understanding of the threshold to criminality - see Law Reform Commission of Canada, Our Criminal Law (Ottawa: Information Canada, 1976) at 33 - this disposition has never raised questions about the propriety of the animal protection provisions long resident in our criminal law, nor of course did it foreclose the state's initiative in the present Bill. On the general part of the 
the Bill, was expressed in ss. 444 to 447 of the Criminal Code. ${ }^{33}$ Section 444 prohibited the wilful killing, injuring, or endangering of cattle; s. 445 prohibited the wilful killing, injuring, or endangering without lawful excuse of all other animals, both domesticated animals and animals not owned by anyone; s. 446 prohibited wilfully causing unnecessary pain, suffering, or injury to any and all animals by any means; and s. 447 prohibited the keeping of a cockpit. Sections 444 and 445 were grouped together under the heading "Cattle and Other Animals," and ss. 446 and 447 under the heading "Cruelty to Animals." The offences created by ss. 445, 446, and 447 are summary conviction offenses (maximum six months' imprisonment or a $\$ 2,000$ fine or both); ${ }^{34}$ section 444 is an indictable offence (imprisonment for not more than five years). All of the sections were contained in Part XI, entitled "Wilful and Forbidden Acts In Respect of Certain Property." Together, these provisions prohibited, as regards all animals, both the "intentional and malicious hurting or killing of an animal either generally or in specific ways that are deemed to be cruel," and "neglect in the provision of necessary food, water, shelter or care." 35

The Bill changes this in a number of ways. First, it repeals ss. 444-447, and relocates the new provisions with respect to animals from Part XI to the new Part V.I, headed "Cruelty to Animals." (Part V of the Code is headed "Sexual Offenses, Public Morals and Disorderly Conduct.") Second, in s. 182.1, it introduces for the first time a definition of "animal" ("a vertebrate, other than a human being, and any other animal that has the capacity to feel pain"). Third, in s. $182.2(1)$ - which the marginal note captions "Killing and harming animals" - it recasts and expands many of the offenses formerly found in ss. 444, 445, 446 and 447. Fourth, it permits, in s. 182.2(2), the Crown to proceed as regards s. 182.2(1) offenses either by indictment (imprisonment for a term of not more than five years) or on summary conviction (fine not exceeding $\$ 10,000$ or imprisonment for a term of not more than eighteen months or both). Fifth, in s. 182.3(1), it recasts and expands the neglect provisions of s. $446(1)^{36}$ and, in s. 182.3(2), defines "negligence" as "departing markedly from the standard of care that a reasonable person would use." Section 182.3(3) permits the Crown to proceed on these offences either on indictment (imprisonment for a term of not more than two years) or by summary conviction (fine not exceeding $\$ 5,000$ or imprisonment for a term

criminal law, see J. Gardner, "On the General Part of the Criminal Law" in A. Duff, ed., Philosophy and the Criminal Law: Principle and Critique (Cambridge: Cambridge University Press, 1998) 205; and A. Ashworth, "Is Criminal Law A Lost Cause?" (2000) 116 L.Q. Rev. 225. R.S.C. 1985 , c. C-46 as amended.

3. But see s. 446(5), which authorizes the court, as regards any of the offenses in s. 446(1) and in addition to any other punishment permitted, to "make an order prohibiting the accused from owning or having the custody or control of an animal or a bird during any period not exceeding two years."

35 I here cite the Department of Justice's own characterization of the offenses created by ss. 444-47. See Canada, Crimes Against Animals: A Consultation Paper (Ottawa: Communication and Executive Services Branch, 1998) at 4, online: <www.canada.justice.gc.ca/en/cons/caa > [hereinafter Paper].

36 The new negligence offenses are "negligently caus[ing] unnecessary pain, suffering or injury to an animal" (s. 182.3(1)(a)); wilful abandonment of an animal by an owner or by person having custody and control or negligently failing "to provide suitable and adequate food, water, air, shelter and care" (s. 182.3(1)(b)); and "negligently injur[ing] an animal while it is being conveyed" (s. $182.3(1)(c))$. 
of not more than six months or both). Sixth, s. 182.4(1) of the Bill expands the authority of courts to make orders, in addition to the penalties specified, prohibiting persons convicted under ss. 182.2(1) and 182.3(1) from "owning, having the custody or control of or residing in the same premises as an animal during any period that the court considers appropriate but, in the case of a second or subsequent offence, for a minimum of five years" and, on the initiative of the Attorney General or on its own motion, ordering the convicted offender to pay restitution "to a person or an organization that has taken care of an animal as a result of the commission of the offence." Finally, in s. 182.6, the Bill creates the offence of wilfully or recklessly poisoning, injuring, or killing "a law enforcement animal while it is aiding or assisting a peace officer or public officer engaged in the execution of their duties." ${ }^{.37}$

These are wholesale changes to the architecture of the law of crimes governing our treatment of animals. And it is proper and necessary to inquire, first, what motivated them, and second, how they affect the place of animals in our law. As regards the first inquiry, I will suggest that the state's stated motivations are drivel that express no more dignified an end than its aim to cater to certain ideological positions. As regards the second much more important, though not unrelated, matter, I will argue that the effect of these provisions is to elevate the status of animals at law. In the conclusion, I shall then make good my intention to argue that this elevation is good neither for them nor for us.

The Department of Justice's Crimes Against Animals: A Consultation Paper ${ }^{38}-$ all twelve pages of it - frames the motivation behind the state's interest in this body of law at both a wholesale and a retail level. The wholesale on offer is a mess: the Paper discloses the state's interest to be a jumble of crude Kantianism ("there is a connection between violence toward animals and violence toward people"), ${ }^{39}$ armchair sociology ("more and more people believe that animal abuse is not taken seriously enough by those within the criminal justice system and by the law itself, and that the Criminal Code is largely ineffective in deterring it"), ${ }^{40}$ and in terrorem gestures ("For most people, it is difficult if not impossible to imagine how someone could injure or torture an animal for no purpose. Yet it happens all too frequently in Canadian society and is very seldom reported"). ${ }^{41}$

When the Paper turns to specifics, intellectual and legal banality of this general sort is replaced by political disingenuousness. Legal change is needed, we are first informed, because "in recent years, many critics ... have argued that an approach that protects animals, even in part, by virtue of their status as property is misguided and offensive, suggests that the law is less concerned with protecting animals as beings capable of

37 "Law enforcement animal" is defined as "a dog, a horse or any other animal used by a peace officer or public officer in the execution of their duties" (s. 182.6(1)). Section 182.6(3) allows the Crown to proceed either on indictment (imprisonment for not more than five years) or by summary conviction (fine of not more than $\$ 10,000$ or imprisonment for not more than eighteen months or both); and s. 182.6(4) permits the court to order restitution.

Paper, supra note 35 . See also Lafreniere, supra note 1.

Paper, ibid. at 4, 2.

Ibid. at 5.

Ibid. at 4. 
suffering than with the protection of human proprietary interests, and does not satisfactorily convey a moral obligation to avoid inflicting unnecessary harm." ${ }^{22}$ Now, quite apart from the bare-faced legal moralism it involves, this rationale minimizes, if indeed it does not belie, the fact that only s. 444 ("Injuring and Endangering Cattle") as it stood before the Bill predicated animal protection on the happenstance of an animal's status as property. What is at hand here has, in consequence, nothing at all to do with a serious-minded engagement with the difficult question of the place of animals at law; rather, what is at play, and what this passage reveals, is the intention to cleanse the law ideologically. This is driven home by the second arm of the state's case, namely, that the law must be changed because "a penalty structure based exclusively on the economic usefulness of the animal is not in accord with the concern for the welfare of animals and their need to be protected from cruelty regardless of their status as property." ${ }^{43}$ Again, only the punishment prescribed by s. 444 was in any significant fashion tied to property status. Nor only that: were the purpose simply to increase the punishment for "the more serious cases of intentional animal cruelty and torture," 44 this could have been accomplished without the wholesale redesign of the law of crimes governing animals.

To uncover the significance of the changes, we must look to the Bill itself for evidence of the nature of the ideological compulsion driving the entire endeavour. A first indication resides in the nature of the offenses in ss. 182.2(1) and 182.3, the main provisions of the new regime. Remarkably, given the rhetoric of the stated intentions, these sections in large measure simply recast the substance of the offenses that existed under ss. 445,446 , and 447 . The novelty of the Bill cannot, in consequence, be said to rest on the substance of the protection it provides animals overall as compared to the former regime.

It does innovate, however, as regards the status of animals in our legal imaginations. This is signalled not only in general terms by the conceptual relocation of the offenses from Part XI to the new Part V.1 (and by the location of that new Part in the overall architecture of the Criminal Code), but also and more specifically by the $\mathrm{s} .182 .1$ definition, by the marginal note to s. 182.2 and even, I think, by the comparison implicit in s. 182.6 to the Criminal Code provisions providing special protection to peace officers. ${ }^{45}$ In all of this, I want to suggest, the Bill intends to elevate the status of animals by compromising the distinction between them and us at law. I want also to suggest that its motivation in doing so is to receive into our law, in significant and troubling measure, the ideology of animal rights. I mentioned previously ${ }^{46}$ that animal rights is distinguished from animal welfarism by its commitment to two concerns in addition to cruelty, namely, the personhood and killing of animals. The just-mentioned features of the Bill speak to both of these concerns. Property status is de-emphasized, not because it has anything to do with animal protection, ${ }^{47}$ but because it impairs our

Ibid. at 5 [emphasis added], 7, 9.

Ibid. at 8, 9.

Ibid. at 8.

Namely, s. 231(4) (killing of peace officer) and s. 270 (assault of peace officer).

Supra note 8.

See supra note 23. 
imagining of animals as persons like us. Animals are defined with reference first to vertebrates, not because such a definition has anything to do with animal suffering, but because vertebrates are the hobby-horse of animal rights proponents, ${ }^{48}$ and because human beings might then be viewed as vertebrates too. "Killing and harming" is the marginal note, rather than "cruelty," not because killing and harming are disallowed, but because the prohibition of killing is the pledge of final accomplishment of the animal rights crusade and because "harming" imports a Millian flavour of personhood. And law enforcement animals deserve special protection, not because they are apt to suffer more, but because they are somehow like peace officers (though, perhaps ironically, they remain owned by police forces).

\section{Conclusion: Calculating Consequence}

There is a deep connection between the way we think about animals and the way we think about ourselves. This connection is not the one Kant drew between our virtue and their vulnerability. Rather, thinking ourselves human depends upon our having a sense, at once, of our belonging to the same body and of the plenitude of being in excess of, and different from, ourselves. Animals are that plenitude, and they are, for us, one of the two foundations of our shared humanity.

Animal activists seek to politicize the body of humankind in service to the good of animals. This they do by making porous the boundaries of the community of fate in which human fellowship alone can take form in order to permit animals residency there. But they are mistaken in this as regards both ourselves and animals. Biopolitics signals not a greater community of being, but the diminishment of the being of human and animal kind. Humans come to occupy just another part of the biomass; and animals become homogenized in us and their alien Otherness tamed by us. This move renders empty human fellowship and makes of animals natives in a bizarre empire of the ontic.

If I am right, Bill $\mathrm{C}-10$ is an instance, albeit minor, of this drive to politicize the human body and to colonize the animal-Other. This it does by compromising the boundaries of the biologic continuum that, between birth and death, defines and makes possible our presence to one another and their presence for us. In the past, racism and sexism insisted upon difference to fragment the biologic unity of humanity in order then to form and to defend differences at law and politics. But extending beyond ourselves the continuum of our shared fate comes with risks no less dangerous or delimiting, both for ourselves and for animals. Politicizing the human body and colonizing - and levelling - animal difference, not only disfigures the very public morality of our law and politics, but, by rendering invisible the alien, cheapens our lives beyond law and politics. 